DOI https://doi.org/10.18551/rjoas.2018-06.17

\title{
PROBLEMS AND SOLUTIONS OF CREATIVE INDUSTRY IN INDONESIA: A CRITICAL AND REFLECTIVE REVIEW
}

\author{
Maulina Erna \\ Business Administration Studies, Faculty of Social and Political Sciences, \\ University of Padjadjaran, Indonesia \\ E-mail: erna.maulina@unpad.ac.id
}

\begin{abstract}
Creative industry in some countries becomes the new economic locomotive. In Indonesia, creative industry is still being developed, and various problems still occur. This paper presents a thorough literature review to describe various problems faced by creative industry players. Solutions were designed based on the described problems. A favorable ecosystem for creative industries created by designing creative city/district is proposed as the solution toward the problems. This idea regards the fact that favorable ecosystem gives positive contribution to the creative industry which eventually improve the economy. This solution offers some benefits seen from the macro indicators including improvement in the export value, employment, forward and backward linkage from subsectors that become the focus of a city/district development.
\end{abstract}

\section{KEY WORDS}

Creative industry, business ecosystem, city plan, economy.

The era of 4.0 industries is dominated by the utilization of digital technology that makes life easier like today. This era had been previously predicted by some experts. Tofler (1970) made a prediction that the development of human civilization will go through three phases. The first phase is the era of agriculture that is characterized by strong feudal system, masculinity, and closeness to the nature. The next phase is the industrial era which is characterized by the rising demand on standardization, democratization, and urbanization. The last phase is the information era where internet, innovation and science dominate the human life.

In line with Tofler's view, creative industry is born as a new stream of economy in some counties including Indonesia. The phenomena of creative industries in America, South Korea, and India are the proof that creative industries give significant contribution to the economic development of those countries. Tofler's prediction (1970) is supported by some hypotheses made by some other researchers including Drucker, 1993; Naisbitt, 1996; Laguna \& Johan, 2005; Osterwalder \& Pigneur, 2010; Davenport et al., 2006; Prasad \& Prasad, 2013.

Particularly in Indonesia, as a new economic locomotive in the national economy, creative industry along with its sixteen sub sectors are currently in the emerging industry phase. According to the result of the survey administered by the Central of Statistics Bureau (Badan Pusat Statistik/BPS) in cooperation with the Central of Creative Industries (Badan Ekonomi Kreatif) in 2017, in aggregate, the contribution of creative industry in Indonesia during the last 3 years has gotten stronger. In 2016, creative industry sectors contributed as much as $7.38 \%$ in the national economy.

The culinary, fashion, and handicraft sectors dominate the sixteen subsectors of creative industries. Specifically, the contribution of each subsector toward the gross national product respectively include the sector of culinary $(41.69 \%)$, fashion $(18.15 \%)$, handicraft (15.70\%), Television and Radio (7.78), publishing (96.29\%), architecture (2.3\%), application and game developer $(1.77 \%)$, advertising $(0.80 \%)$, music $(0.47 \%)$, photography $(0.45 \%)$, art performance $(0.45 \%)$, product design $(0.24)$, fine art $(0.22 \%)$, interior design $(0.16 \%)$, film (0.16\%), and visual communication design (0.06\%). BPS \& Bekfraf RI (2017). 
The Problems of Creative Industries in Indonesia. Various problems occur in the field of creative industry. Sugiono et al., (2017) have identified problems that need immediate solution including: first, the uneven distribution of resources among the sixteen sub sectors of creative industry. This can be seen from the export activities in creative industry which is dominated by only 3 (three) subsectors which are fashion industry $(56 \%)$, handicraft industry $(37 \%)$, culinary industry $(6 \%)$, while the other thirteen subsectors only make $0.5 \%$ up to $1 \%$ contribution.

Second, seen from geographical aspect, resources for creative industry have not yet been evenly distributed throughout Indonesia. Industries in Java island still dominates the export activities in this industry. The data show the contribution of each province in Java which is dominated by West Java $33.56 \%$, East Java $20.85 \%$, Banten $15.66 \%$, Central Java $14.02 \%$, Special Region of Jakarta $10.50 \%$. Areas outside Java only make small contribution such as Riau Islands $1.86 \%$, Bali $1.32 \%$, North Sumatera $0.28 \%$, and Riau $0.45 \%$. This data indicate that the ecosystem of creative economy in most areas (especially the ones outside Java) have not yet been developed well.

Third, it takes more massive and creative efforts in creating new market, and penetrating the already existing market especially international market/export. Recently, the export of creative industry products is limited to only some countries with an average percentage of less than $5 \%$. The destination countries of export activities include United States (31.72\%), Japan (6.74\%), Taiwan (4.99\%), Switzerland (4.96\%), Germany $(4.56 \%)$, Singapore (3.82\%), China (3.49\%), Hongkong (3.02\%), Belgium $(2.93 \%)$ and the UK $(2.86 \%)$.

Fourth, workers in the creative industry still need supports and contribution from highlyeducated workers. Currently, workers in this sector are dominated by high school graduates $(57.20 \%)$, secondary school and below (36.10), while only $6.70 \%$ of them are college graduates. This result is equal to the professional status of the workers. Most of workers in this sector are blue collar workers (sales marketing staffs, service staffs, production staffs, and other staffs) and only few of them are white collar workers (professional staffs, technicians, or experts).

Fifth, only few creative industry units $(16.58 \%)$ have received legal status while the rest $83.32 \%$ have not yet received legal status; sixth, the lack of access to capital resources also appears to be an issue as most of creative industry players $(92.37 \%)$ used their own capital resources; Seventh, creative industry players still market their products and service directly to the consumers in domestic market $97.36 \%$, in a city/district $68.84 \%$, outside a city/district $8.41 \%$; Eighth inadequate research and development in this sector is also an issue where most of creative industry player never conducted any research and development; Ninth, many players in this sector have not yet registered or joined the association of creative industry players. Only most players from the TV, Radio and Architecture sectors have been registered in the association.

Building Favorable Business Ecosystem. Solving the problems that occur in the field of creative industry demand strong role and collaboration among some stakeholders. A penthahelix collaboration among business players, government, communities, academicians, and mass media is considered necessary in supporting the creation of conducive ecosystem for creative industry development. A well-established ecosystem build through a dynamic collaboration among those five actors is expected to give positive contribution to the development of business in general, and support the development of creative industry in facing dynamic business condition (Veal \& Mouzas, 2010; Adner, 2006; Ceccagnoli, et al., 2012; Ben Letaifa, et al., 2013; Gobble, 2014).

One of mondial strategies used in the development of creative economy Indonesia is a program namely "creative city". Studies conducted in various countries have proposed the implementation of creative city program in developing a conducive ecology for creative economy, as the program has been proven to have positive and significant influence on the development of the creative economy (Landry \& Comedia, 2000; Florida, 2002; Howkins, 2009). 
A framework proposed by Nee (2003) through the new institutionalism economics and sociology (NTES) can be used as the reference in developing a favorable ecosystem for creative industry. Nee (2003) integrates the role of state regulation (macro), organizations/industries (meso) and business players/individuals (micro). A set of rules that represent normative, regulative, and cultural-cognitive aspects applies in each level. This model offers a realistic requirement that is suitable to be implemented in Indonesia which has diverse social and cultural conditions and different amount of resources. This diversity is a potential aspect that supports the creative industry to develop various products.

Within the macro level, the government holds a dominant role, especially related to the institutional aspect. Government's role can be enhanced by strengthening the concepts/strategies through; legal policies (acts, regulations, presidential decrees, ministerial regulations, etc); institutions (organizations, structure, system, human resources); operational area; organizational (business profit) and outcome (social and economic contribution).

In the meso level, the presence of associations from each sub-sector is important to build a healthy industrial ecosystem (Tullock, 2005). The presence of related associations is expected to accommodate various needs related to information sharing and information actualization in each subsector of creative industry. Business associations provide a place for stakeholders to maintain good relationship.

In the micro level, as players in a business activities that use knowledge and creativity as the main capital, creative industry players cannot be separated apart from the environmental dynamicity that eventually forms a business ecosystem. Hence, the business activities of creative industry cannot be merely seen from the economical point of view (market and resource-based view). In fact, creative industry is able to add the values of social, cultural, and environmental aspects which finally improve the competitiveness of a nation.

The development of favorable ecosystem for the creative industry through the creation of creative city is an interesting topic as taps on several points. First, the availability of massive resources and cultural diversity; Second, the availability of various financing scheme offered by the fintech/tekfin industry; Third, market expansion through infrastructure development due to trade liberalization and and advancement of technology; Fourth, adaptive institutional support; Fifth, favorable business climate; Sixth, the composition of human resources that is oriented to demographic surplus $(63 \%$ of 237 population are in the productive age between $15-55$ years old, and $27 \%$ of them are young generation aged between $16-30$ years old) which reflects the number of creative people that is estimated approximately 11.4 million creative people (BPS RI, 2010).

Seen from the business sustainability, creative economy appears to the only one industry that is able to collaborate various potentials as previously explained. Creative industry improves the values of various resources through creativity and innovation. In addition, creative economy also contributes to the social and cultural aspects of a nation as it strengthens the national identity. This industry also offers better quality of life and enhances the prosperity of the society, besides it also improves the social tolerance.

The development of creative city is the concrete reconstruction of creative business ecosystem. From the reconstruction, a benchmark that shows that effective and efficient way in developing the creative economy through collaboration among various parties can be obtained to support the realization of conducive business ecosystem. Moreover, the reconstruction also motivates other cities to develop and make their business ecosystem more conducive to support the development of creative economy through breakthrough offered by the stake holders who are involved in the process. Kemenparektraf (2014) has mapped the creative industry ecosystem consisting of a chain of creative values, environment, development, market and archiving which are inter-correlated. However, seen from the framework of the holism view, the reconstruction of creative industry is also influenced by other factors other than the four factors mentioned above. Some other factors are believed to influence the sustainability of certain enterprises within the creative industry ecosystem. 
Simultaneous Agenda in Each Level. Within a more operational level, those variables can be developed into a framework that improves the quality and quantity of the creative city development. In the macro level, some urgent agendas demand immediate realization. First, the government regulations (both central and regional government) that improve the competitiveness in the macro level. Second, the implementation of collaborative governance as the realization of penthahelix collaboration. Third, high-quality education to educate creative individuals that festive various social events such as cultural festival, food festival, bazaar, concerts and other events. Fourth, supports to live up a city by organizing both national and international class thematic events in order to strengthen the quality of local identities through traditional food and handicrafts.

Fifth, more incubation programs in the forms of various exhibition events that engage people to actively involved in the events in various levels. It is also necessary to conduct training on event organizing to enhance the efficiency and effectiveness in organizing various events (more effective and efficient use of time, budget, quality and promotion) which is expected to improve the quality of various cultural institutions. Sixth, better distribution of high-speed internet. Seventh, conducting financial gathering. Eighth, development of physical infrastructure (public space, park, pedestrian spots and social interaction space) and other infrastructure development. Ninth, improvement in the collaboration and the network of creative cities to obtain different benchmarks from other creative cities.

In the meso level, the focus relies more on the collective action, monitoring and enforcement done to improve the competitiveness of creative industry players. This can be done by supporting various cultural collaboration among different cultures to create strong forward and backward linkage that improves the quality and quantity of cultural projects across communities/culture/sub-sectors.

The development of creative city in the micro level can be done through two ways (i) improvement of individual creativity through various programs/events that facilitates individuals as creative economy players to experience renewal ability; (ii) improvement of managerial creativity (from self employee to start-up entrepreneurs) within both marketbased and resource-based views (Barney, 1991) that enables the players in this industry to design certain formulation, implementation and evaluation strategies with stronger emphasis on the function and role of decoupling and compliance/consensus. Adequate realization of those two aspects strengthens the embeddedness/bound between the two levels (Florida, 2002 ; Landry \& Comedia, 2000 ; Howkins, 2002, 2009 ; Fitriani, 2015).

Conclusion. As a new locomotive in national economy, creative industry in Indonesia is still facing various issues, preventing this industry to give maximum contribution to the economy. This paper proposes a strategy to build business ecosystem using the penthahelix collaboration. Concrete realization of the collaboration can be done by implementing a program namely creative city development. Every city/district is expected to formulate and pick up some sectors out of the sixteen sub-sectors of creative industry that match their local potentials to be further enhanced.

The selection of sub-sectors should consider some points including (i) adequate collaboration among penthahelix actors; (ii) the selected sectors should have stronger leverage than other sectors which can be identified by investigating the role of other subsectors / forward and backward linkage of the selected sub-sectors; (iii) the employment capacity; (iv) the contribution of each subsector to the national economy that can be measured from the export activities.

\section{REFERENCES}

1. Adner, R. 2006. Match Your Innovation Strategy to Your Innovation Ecosystem. Harvard Business Review 84 (4): 98-107.

2. Barney, Jay. B, 1991. Firm Resources and Sustained Competitive Advantage. Journal of Management.(17)1: 99-121. 
3. Ben Letaifa Soumaya, Anne Gratacap, Thierry Isckia, 2013. Understanding Business Ecosystems: How Firms Succeed in the New World of Convergence. De Boeck Superieur S.A. Bruxelees. Belgium.

4. Ceccagnoli, M., C. Forman, P. Huang, and D. Wu. 2012.Cocreation of Value in a Platform Ecosystem: The Case of Enterprise Software. Management Information Systems Quarterly 36 (1): 263-90.

5. Charles Landry \& Comedia, 2000. The Creative City: A Toolkit for Urban Innovators. Earthscan Publication. London

6. Davenport, Thomas $\mathrm{H}$,et.al, 2006. Strategic Management in the Innovation Economy: Strategy Approaches and tools for dynamic innovation capability. John Willey.

7. Drucker, Peter F. 1993. Post Capitalist Society. Harper Collins Publisher. New York.

8. Fitriani, Rachma. 2015. Menguak Daya Saing UMKM Industri Kreatif: Sebuah Riset Tindakan Berbasis Soft System Methodology. Yayasan Obor Indonesia.

9. Gobble, M. 2014. Charting the Innovation Ecosystem. Research Technology Management 57 (4): 55-9.

10. Florida, Richard L, 2002. The Rise of Creative Class: And How It's Transforming Work, Leisure, Community and Everyday Life. Basic Book. New York.

11. Howkins, John, 2002. The Creative Economy: How People Make Money From Ideas. Penguin London.

12. 2009. The Creative Ecologies: Where Thinking is a Proper Job. University Of Quensland Press.

13. Jackson, Michael C, 2003. System Thinking: Creative Holism for Managers. John Wiley \& Sons, Ltd

14. Laguna, Manuel \& Marklund, Johan, 2005. Business Process Modelling, Simulation, and Design. New Jersey: Pearson Prentice Hall.

15. Naisbitt, Jhon, 1996. Mega Trends Asia, Eight Asian Megatrends That are Reshaping Our World. Simon \& Schuster.New York.

16. Nee, Victor.2003. The New Institutionalism in Economic and Sociology. Center of Study Economy and Society. Vol.4.November 2003.

17. Osterwalder, Alexander \& Yves Pigneur, 2010. Business Model Generation. Jhon Wiley \& Sons, Inc, Hoboken New Jersey.

18. Porter, M. 1980. Competitive Strategy. New York. Free Press

19. 1981. The Contribution of Industrial organization to Strategic Management. Academy of Management Review 6. 20-609.

20. Prasad Anshuman \& Prasad Pushkala, 2013. Innovation in the global age: Implication for Business and in the Knowledge Economy. International Journal Of Business Administration. Vol 4. No. 6.

21. Sugiono, Arif, Ria Arifianti, Sam'un JR, Erna Maulina, 2017. Dynamic Capabilities: Strategi dan Kunci Sukses Persaingan dalam Bidang Industri Kreatif. Yogyakarta: Penerbit Ombak.

22. Tofler, Alfin, 1970. Future Shock, Random House, New York.

23. Tullock, Gordon, 2005. The Rent seeking Society. Liberty Fund

24. Tullock, Gordon, 2005. Public Goods, Redistribution and Rent Seeking. Edward Elgar Publishing Limited.

25. Veal, Gareth, Stefanos Mouzas, 2010. Learning to collaborate: a study of business networks. Journal of Business \& Industrial Marketing, Vol. 25 Issue: 6, pp.420-434, https://doi.org/10.1108/08858621011066017

26. 2014. Ekonomi Kreatif: Kekuatan Baru Indonesia Menuju 2025.Kementerian Pariwisata dan Ekonomi Kreatif RI.

27. 2014. Ekonomi Kreatif: Kekuatan Baru Indonesia Menuju 2025. Rencana AKsi Jangka Menengah 2015-2019. Kementerian Pariwisata dan Ekonomi Kreatif RI.

28. 2010. Hasil Sensus Penduduk. Badan Pusat Statistik Republik Indonesia.

29. 2017. Data Statistik Hasil Survey Ekonomi Kreatif. Biro Pusat Statistik dan Badan Ekonomi Kreatif Republik Indonesia. 